\title{
Proteksi Atas Barang Milik Daerah Dalam Mewujudkan Akuntabilitas di BPKAD Provinsi Sumatera Utara
}

\author{
Dito Aditia Darma Nasution ${ }^{1}$ \\ Fakultas Sosial Sains Universitas \\ Pembangunan Panca Budi, Indonesia. \\ Email: ditoaditia@dosen.pancabudi.ac.id
}

\author{
Erlina $^{2}$ \\ Fakultas Ekonomi dan Bisnis \\ Universitas Sumatera Utara, \\ Indonesia.
}

\begin{abstract}
ABSTRAK
Penelitian ini bertujuan untuk menganalisis dan mendeskripsikan bagaimana penerapan proteksi Barang Milik Daerah dalam mewujudkan akuntabilitas di BPKAD Provinsi Sumatera Utara. Metode yang digunakan dalam penelitian ini adalah pendekatan kualitatif dengan melakukan wawancara kepada pegawai di bidang akuntansi dan aset. Hasil penelitian menunjukkan bahwa proteksi Barang Milik Daerah di BPKAD Provinsi Sumatera Utara sudah efektif namun belum akuntabel. Keterbaruan dari penelitian ini yang membedakannya dari penelitian sebelumnya yaitu peneliti memasukkan unsur Pendapatan Asli Daerah (PAD) untuk menilai akuntabilitas dalam proteksi Barang Milik Daerah.
\end{abstract}

Kata Kunci : Proteksi Barang Milik Daerah; Pendapatan Asli Daerah; Akuntabilitas.

\section{Protection Of Regional Property In Realizing Accountability In BPKAD Of North Sumatera Province}

\begin{abstract}
This research aims to analyze and describe the implementation of Regional Property protection in realizing accountability in BPKAD of North Sumatera Province. The method uses in this research is qualitative approach by interviews with employees in the field of accounting and assets. The result shows that the Regional Property protection in BPKAD of North Sumatera Province was effective but was not accountable yet. The newness that made this research different from previous research was researcher added Native Revenue (PAD) to assessed accountability in protect possession of the region.
\end{abstract}

Keywords: Regional Property Protection; Regional Original Income; Accountability.

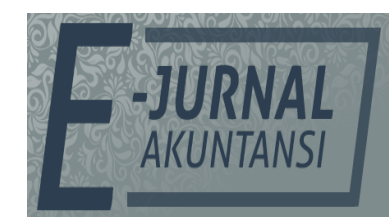

E-JA

e-Jurnal Akuntansi e-ISSN 2302-8556

Vol. 29 No. 2

Denpasar, November 2019

Hal. 779-790

Artikel masuk:

20 Oktober 2019

Tanggal diterima: 19 November 2019 


\section{PENDAHULUAN}

Revisi atau perubahan atas Undang-undang Nomor 32 tahun 2004 menjadi Undang-undang Nomor 23 tahun 2014 tentang Pemerintahan Daerah mengakibatkan terjadinya perubahan penyelenggaraan sistem pemerintahan dari yang sifatnya sentralistik menjadi bersifat desentralistik, sehingga diperlukan suatu pengelolaan atas manajemen pemerintahan daerah. Pengelolaan atas manajemen pemerintahan daerah yang efektif diperlukan agar segala urusan pemerintahan yang kewenangannya telah dilimpahkan kepada daerah dapat dilaksanakan secara optimal dan dapat dipertanggungjawabkan kepada rakyat (Assey et al, 2017). Menurut (Henoch \& Sauter, 2016) salah satu bentuk pertanggungjawaban kepada rakyat adalah pertanggungjawaban atas Barang Milik Daerah (BMD).

Perlunya atas peningkatan pertanggungjawaban terhadap BMD didasari oleh Peraturan Pemerintah Nomor 58 Tahun 2005 tentang Pengelolaan Keuangan Daerah, yang mana mengharuskan penyampaian pertanggungjawaban atas pelaksanaan Anggaran Pendapatan dan Belanja Daerah (APBD) dalam bentuk laporan keuangan yang disusun melalui suatu proses akuntansi atas transaksi keuangan. BMD berkaitan dengan pos persediaan, aset tetap dan aset lainnya dalam laporan keuangan. Maka, diperlukan khusus dari entitas pemerintah daerah. Tentu tidak berlebihan bila melihat kontribusi pengelolaan BMD bagi jalannya roda pemerintahan, pelayanan kepada masyarakat, dan salah satu acuan yang digunakan oleh Badan Pemeriksa Keuangan Republik Indonesia (BPK-RI) dalam memberikan opini.

Kendala yang sering dihadapi oleh pemerintah daerah dalam melaksanakan proteksi BMD selain terbatasnya sumber daya manusia yang ahli dan kompeten adalah belum tegasnya penerapan peraturan perundangundangan yang terkait (Lee et al, 2015). Hal tersebut mengakibatkan munculnya berbagai permasalahan dalam proteksi BMD. Beberapa permasalahan diantaranya belum adanya sertifikasi atas aset tanah atau aset tanah sudah tersertifikasi namun belum atas nama pemerintah daerah, aset diklaim pihak lain, aset yang tidak diketahui keberadannya, serta masih lambatnya penyelesaian dokumen kepemilikan aset (Kaganova \& Telgarsky, 2018).

Proteksi BMD di Provinsi Sumatera Utara memiliki dasar hukum berupa Peraturan Menteri Dalam Negeri Nomor 19 Tahun 2016 tentang Pedoman Pengelolaan Barang Milik Daerah, dan Peraturan Pemerintah Nomor 27 Tahun 2014 tentang Pengelolaan Barang Milik Negara/Daerah. Pada Peraturanperaturan tersebut disebutkan bahwa BMD merupakan semua barang yang dibeli atau diperoleh atas beban APBD atau dari perolehan lainnya yang sah.

Provinsi Sumatera Utara adalah provinsi yang mempunyai beragam aset baik yang berasal dari APBD maupun dari perolehan lainnya yang sah. Perolehan lainnya yang sah dapat berasal dari hibah masyarakat atau hibah dari Pemerintah Pusat. Badan Pengelolaan Keuangan dan Aset Daerah (BPKAD) Provinsi Sumatera Utara menyebutkan pada tahun 2018 nilai aset Provinsi Sumatera Utara mengalami peningkatan yang signifikan yaitu sebesar Rp289.321.729.433,00 karena terdapat pelimpahan aset yang telah jatuh tempo masa kontraknya. Aset yang berada di bawah kewenangan daerah tersebut wajib dikelola oleh pemerintah daerah secara baik dan benar. Maka dari itu, 
dibutuhkan sebuah sistem untuk mengelola BMD agar pemanfaatannya memungkinkan untuk memberikan kontribusi yang dapat menaikkan Pendapatan Asli Daerah (PAD).

Meningkatnya pendapatan asli daerah sebagai hasil dari pemanfaatan BMD diharapkan dapat memberikan kontribusi yang baik ke arah yang positif terhadap pembangunan infrastruktur secara berkelanjutan (Fuchs et al, 2017). Selain itu kontribusi BMD terhadap pendapatan asli daerah juga dapat digunakan sebagai salah satu indikator dalam menilai akuntabilitas pemerintah daerah dalam pengelolaan kekayaan daerah (Rothschild \& Block, 2016). Berdasarkan Peraturan Menteri Dalam Negeri Nomor 19 tahun 2016 tentang Pedoman Pengelolaan Barang Milik Daerah, bentuk pemanfaatan BMD diantaranya dalam bentuk sewa, pinjam pakai, kerjasama pemanfaatan, bangun guna serah, dan kerjasama penyediaan infrastruktur.

Apabila pemerintah daerah dalam hal ini BPKAD Provinsi Sumatera Utara tidak mengamankan BMD yang berpotensi, maka pengelolaan tidak akan dapat efektif dan efisien. Sehingga perlu dilakukan proteksi terhadap Barang Milik Daerah baik dari segi administrasi, fisik, maupun hukum agar pemanfaatan BMD dapat lebih optimal serta untuk menghindari kegiatan penyerobotan, diambil alih, atau klaim oleh pihak-pihak yang tidak bertanggungjawab (Zeng \& McLaren, 2015).

Pelaksanaan APBD Provinsi Sumatera Utara tahun 2018 memperoleh opini Wajar Tanpa pengecualian (WTP) dari BPK-RI, hal ini merupakan perolehan opini WTP untuk yang kelima kalinya secara beruntun terhitung sejak tahun 2014 hingga 2018, menurut Gubernur Sumatera Utara Edy Rahmayadi perolehan opini WTP ini merupakan perwujudan pengelolaan keuangan yang yang sehat dan juga didukung dengan sistem pengendalian intern yang efektif, serta dipatuhinya peraturan perundang-undangan. Perolehan opini WTP tersebut tentunya harus tetap dipertahankan, salah satunya dengan cara menjaga akuntabilitas pemerintah daerah dalam bidang pengelolaan aset daerah (Irwin, 2015).

Muda et al (2017) menyebutkan bahwa realisasi kegiatan proteksi aset Pemerintah Provinsi Sumatera Utara secara administratif, fisik, dan hukum tidak berjalan efektif tapi sudah akuntabel. (He et al (2016) berpendapat bahwa pengelolaan aset daerah selama ini telah berjalan, namun belum terlaksana sebagaimana yang diharapkan untuk mencapai daya guna dan hasil guna yang maksimal. Sesuai dengan penjabaran di atas, maka peneliti tertarik untuk meneliti tentang Proteksi atas Barang Milik Daerah dalam Mewujudkan Akuntabilitas di BPKAD Provinsi Sumatera Utara.

\section{METODE PENELITIAN}

Penelitian ini dilaksanakan dengan pendekatan penelitian kualitatif dan jenis penelitian deskriptif untuk menjelaskan proteksi BMD dalam mewujudkan akuntabilitas di BPKAD Provinsi Sumatera Utara. Penelitian ini dilakukan di BPKAD Provinsi Sumatera Utara bagian Akuntansi dan Aset dengan waktu penelitian kurang lebih selama 5 bulan yang dimulai pada bulan Mei 2019 hingga bulan September 2019. Sumber data berasal dari data primer dan data 
sekunder yang diperoleh dari hasil wawancara dan dokumentasi (Maxwell \& Reybold, 2015).

Data primer diperoleh dari hasil wawancara dengan tiga informan yaitu Kepala Sub Bidang Penatausahaan Aset, Staf Bidang Akuntansi dan Aset, serta Kepala Bidang Akuntansi dan Aset. Peneliti memilih informan berdasarkan topik penelitian serta yang dianggap paling kredibel untuk menjawab permasalahan penelitian. Maka dari itu peneliti menetapkan ketiga informan tersebut karena beliau bertiga adalah orang-orang yang terlibat secara langsung dalam kegiatan proteksi BMD.

Adapun data sekunder dalam penelitian ini diperoleh dari catatan-catatan, dokumen-dokumen yang digunakan serta arsip resmi BPKAD Provinsi Sumatera Utara terkait kegiatan proteksi BMD selama tahun 2017-2018. Catatan tersebut diataranya yaitu Standar Operasional Prosedur (SOP) proteksi BMD, Kartu Inventaris Barang (KIB), daftar aset tetap Pemerintah Provinsi Sumatera Utara, serta data Realisasi Retribusi Pemakaian Kekayaan Daerah.

Teknik keabsahan data yang digunakan pada penelitian ini adalah berupa uji credibility (validitas internal) atau kepercayaan terhadap hasil penelitian dengan triangulasi (Moen \& Middelthon, 2015). Triangulasi yang digunakan adalah triangulasi sumber dan triangulasi teknik. Peneliti memilih triangulasi sumber dan teknik dengan alasan efisiensi waktu, sehingga peneliti tidak menggunakan triangulasi waktu. Hal ini dikarenakan pada triangulasi waktu membutuhkan wawancara berulangkali dan secara terus menerus yang akan dapat menunda proses pengumpulan data di lapangan (Hinrichs et al, 2017).

\section{HASIL DAN PEMBAHASAN}

González et al (2018) menyatakan bahwa proteksi adalah suatu tindakan untuk mengendalikan serta menertibkan usaha pengurusan BMD yang terdiri atas proteksi administrasi, proteksi fisik, dan proteksi hukum. Hasil dari penelitian Arnitasari (2013) menunjukkan bahwa proteksi aset Pemerintah Provinsi Jawa Timur belum efektif namun sudah akuntabel. Proteksi aset milik Pemerintah Provinsi Jawa Timur dikatakan belum efektif karena belum mampu mencapai sasaran keberhasilan yang diharapkan, baik dari segi proteksi administrasi, proteksi fisik, maupun proteksi hokum Arnitasari (2013).

Kondisi tersebut bertolak belakang dengan hasil penelitian yang ditemukan oleh peneliti, di mana berdasarkan wawancara yang dilakukan peneliti kepada para informan yang bertugas serta melalui pengumpulan dokumen yang berkaitan dengan proteksi BMD diperoleh hasil bahwa proteksi BMD, meliputi proteksi administrasi, proteksi fisik, dan proteksi hukum yang dilakukan oleh BPKAD Provinsi Sumatera Utara sudah berjalan secara efektif namun belum akuntabel.

Berikut kutipan wawancara dengan para informan terkait dengan mekanisme proteksi BMD oleh BPKAD Provinsi Sumatera Utara. Menurut pernyataan dari para informan, proteksi BMD oleh BPKAD Provinsi Sumatera Utara dapat dikatakan sudah efektif dilihat dari telah dilaksanakannya kegiatan proteksi BMD yang sesuai dengan peraturan perundang-undangan yang berlaku. Pernyataan dari Kepala Sub Bidang Penatausahaan Aset adalah sebagai berikut: 
“Terkait dengan landasan hukum kita memakai 3 (tiga) landasan hukum. Yang pertama adalah Peraturan Pemerintah PP Nomor 27 Tahun 2014 tentang Pengelolaan Barang Milik Negara/Daerah, kemudian lebih khusus lagi kita memiliki Peraturan Daerah Provinsi Sumatera Utara tentang Pengelolaan BMD, kemudian terkait dengan perincian pelaksanaan teknis pelaksanaan kita mengacu pada Peraturan Menteri Dalam Negeri Nomor 19 Tahun 2016 tentang Pedoman Pengelolaan BMD."

Pernyataan yang sama juga diungkapkan oleh Staf Bidang Akuntansi dan Aset:

"Kalau landasan hukumnya kami menggunakan Peraturan Menteri Dalam Negeri Nomor 19 Tahun 2016 tentang Pengelolaan BMD, kemudian itu ada turunannya berupa Peraturan Daerah."

Demikian juga pernyataan dari Kepala Bidang Akuntansi dan Aset BPKAD Provinsi Sumatera Utara:

"Iya untuk proteksi itu prinsipnya kita ada Peraturan Menteri Dalam Negeri Nomor 19 Tahun 2016 tentang Pedoman Pengelolaan Barang Milik Daerah, kemudian dikuatkan dengan Peraturan Daerah. Jadi Peraturan Menteri Dalam Negeri itu acuan adalah dari pusat, kemudian untuk muatan lokalnya tadi berupa Peraturan Daerah."

Proteksi administrasi merupakan kegiatan pengendalian dalam pengurusan BMD dengan menghimpun, mencatat, dan menyimpan bukti kepemilikan atas barang dengan tertib dan aman. BPKAD Provinsi Sumatera Utara telah melakukan kegiatan proteksi administrasi sesuai dengan peraturan perundang-undangan yang berlaku. Dimana kegiatan proteksinya meliputi kegiatan: 1) penghimpunan, pencatatan, dan penyimpanan seluruh bukti kepemilikan atas aset dengan tertib dan aman; serta 2) melakukan inventarisasi BMD pada setiap 5 tahun sekali untuk mengetahui kondisi yang sebenarnya atas BMD. Kegiatan proteksi administrasi yang dilakukan BPKAD Provinsi Sumatera Utara tersebut telah sesuai dengan Peraturan Pemerintah Nomor 27 Tahun 2014 tetang Pengelolaan Barang Milik Negara/Daerah Pasal 44 ayat (1); Peraturan Menteri dalam Negeri Nomor 19 Tahun 2016 tentang Pedoman Pengelolaan Barang Milik Daerah; serta Peraturan Daerah Provinsi Sumatera Utara.

Proteksi fisik merupakan kegiatan yang dikerjakan agar secara fisik BMD terhindarkan dari persoalan menurunnya fungsi dan jumlah barang, hingga kehilangan barang. Proteksi fisik BMD di BPKAD Provinsi Sumatera Utara meliputi: 1) Untuk aset tanah proteksi dilakukan dengan pemasangan pagar pembatas, pemasangan patok atau prasati, pemasangan papan nama, serta melakukan penjagaan bila diperlukan; 2) Untuk proteksi fisik terhadap gedung dan bangunan dilakukan dengan cara memasang pagar, memasang bukti kepemilikan, memasang CCTV, dan menyediakan satuan proteksi (bekerjasama dengan Satuan Polisi Pamong Praja); dan 3) Untuk aset kendaraan dinas proteksi fisik dilakukan dengan mewajibkan pihak pengguna/peminjam kendaraan dinas membuat surat pernyataan tanggungjawab risiko. Kegiatan proteksi fisik tersebut sesuai dengan Peraturan Menteri Dalam Negeri Nomor 19 Tahun 2016 tentang Pedoman Pengelolaan Barang Milik Daerah Pasal 299 ayat (1), Pasal 303 ayat (1), dan Pasal 305 ayat (2). 
Proteksi hukum merupakan tindakan proteksi yang dilakukan terhadap BMD yang bermasalah dengan pihak lain. Di mana proteksi hukum yang dilakukan oleh BPKAD Provinsi Sumatera Utara meliputi: 1) proteksi hukum untuk aset tanah dilakukan dengan pembuatan sertifikat tanah, sedangkan untuk tanah yang sudah tersertifikasi namun belum atas nama pemerintah daerah maka dilakukan sertifikasi ulang; 2) proteksi hukum terhadap gedung dan bangunan dilakukan melalui pelengkapan Izin Mendirikan Bangunan (IMB); dan 3) melakukan proteksi hukum terhadap kendaraan dinas dengan melengkapi Bukti Pemilikan Kendaraan Bermotor (BPKB). Kegiatan proteksi hukum yang dilakukan BPKAD Provinsi Sumatera Utara telah sesuai dengan Peraturan Pemerintah Nomor 27 Tahun 2014 tentang Pengelolaan Barang Milik Negara/Daerah Pasal 43 ayat (1), ayat (2), dan ayat (4); Peraturan Menteri Dalam Negeri Nomor 19 Tahun 2016 tentang Pedoman Pengelolaan Barang Milik Daerah Pasal 308 ayat (2); dan Peraturan Daerah Provinsi Sumatera Utara Nomor 08 Tahun 2015 tentang Pengelolaan Barang Milik Daerah Pasal 39 ayat (1), ayat (2), dan ayat (3). Hal ini sesuai dengan hasil wawancara dengan beberapa pihak. Kepala Sub Bidang Penatausahaan Aset menyebutkan bahwa:

"Kalau proteksi hukum ini kita melengkapi bukti kepemilikan atas tanah, jadi sertifikat tanah yang belum memiliki sertifikasi dan tanah yang belum atas nama pemerintah Provinsi Sumatera Utara kita lakukan sertifikasi untuk proteksi terhadap tanah. Kalau proteksi terhadap gedung dan tanah seperti tadi ada IMB, kalau hukum terkait dengan bukti kepemilikan."

Pernyataan tersebut didukung dengan pernyataan dari Kepala Bidang Akuntansi dan Aset:

“...kemudian ada proteksi yang sifatnya legal, contohnya proteksi dalam bentuk sertifikasi tanah."

Kegiatan proteksi BMD yang dilakukan oleh BPKAD Provinsi Sumatera Utara dikatakan efektif karena telah dilakukan sesuai dengan peraturan perundang- undangan yang berlaku yaitu, Peraturan Pemerintah Nomor 27 Tahun 2014 tentang Pengelolaan Barang Milik Negara/Daerah, Peraturan Menteri Dalam Negeri Nomor 19 Tahun 2016 tentang Pedoman Pengelolaan Barang Milik Daerah, dan Peraturan Daerah Provinsi Sumatera Utara tentang Pengelolaan BMD. Indikator lain yang dapat dijadikan sebagai tolok ukur efektivitas proteksi BMD yang dilakukan BPKAD Provinsi Sumatera Utara juga dapat dilihat dari pencapaian target jumlah barang yang telah diamankan hingga mencapai $90 \%$ - 100\% pada setiap tahun anggaran. Hal ini didukung oleh pernyataan dari Kepala Bidang Akuntansi dan Aset:

"Targetnya tersebut puji tuhan telah terpenuhi pada setiap tahunnya, karena memang kita telah melakukan pendataan, yaitu melihat dari data survei sebelumnya juga begitu jadi puji tuhan targetnya selalu terpenuhi. Mudahmudahan $90 \%$ dari target sampai dengan 100\%, karena kan 90\% nya itu ada harga anggaran kemudian realisasinya bisa jadi harganya lebih rendah dibandingkan anggarannya, seperti itu. Tapi kalau melihat jumlah mudahmudahan $100 \%$ telah terpenuhi targetnya."

Pernyataan beliau tersebut didukung oleh pernyataan dari Staf Bidang Akuntansi dan Aset: 
"Iya untuk target insyallah sudah tercapai ya, karena memang kita setiap tahun menggali data aset-aset yang belum tersertifikasi. Mungkin sekitar $90 \%$ an lebih lah, saya data persisnya kurang begitu hafal tapi bekisar pada angka persetase tersebutlah."

Dalam melakukan pelaksanaan proteksi atas BMD, BPKAD Provinsi Sumatera Utara juga banyak mengalami kendala dalam pelaksanaannya. Kendala tersebut terjadi pada setiap jenis proteksi, baik proteksi administrasi, proteksi fisik, dan juga proteksi hukum. Akan tetapi dengan selalu melakukan koordinasi secara baik dan intens dengan para pihak internal maupun eksternal, maka BPKAD Provinsi Sumatera Utara hampir selalu mampu menemukan win solution atas setiap kendala yang terjadi terkait proteksi BMD. Kendala dan solusi yang dilaksanakan BPKAD Provinsi Sumatera Utara dipaparkan sebagai berikut.

Kendala dalam proteksi administrasi meliputi kurang lengkap dan kurang informatifnya catatan atas BMD sehingga memunculkan kerancuan dari pihakpihak yang memerlukan informasi, serta kurangnya kompetensi dari pegawai yang bersangkutan dalam mengoperasikan aplikasi yang digunakan untuk inventarisasi aset, yaitu aplikasi SIMDA-BMD. Solusi yang diterapkan BPKAD Provinsi Sumatera Utara untuk mengatasi kendala tersebut yaitu melakukan rekonsiliasi atas BMD yang tercatat dalam aplikasi SIMDA-BMD dengan data/catatan yang ada, dan juga mengirimkan pegawainya untuk meminta bimbingan langkah penggunaan aplikasi kepada Badan Pengawas Keuangan dan Pembangunan (BPKP) Provinsi Sumatera Utara yang ada di Kota Medan.

Berikutnya yaitu kendala dalam proteksi fisik BMD yaitu adanya penyerobotan atas aset pemerintah daerah oleh pihak yang tidak bertanggungjawab. Pihak-pihak yang tidak bertanggunjawab tersebut membangun bangunan secara permanen di atas tanah milik pemerintah daerah, sehingga menimbulkan dilema bagi pemerintah daerah untuk melakukan penggusuran ataukah tidak. Solusi dari permasalahan tersebut terdiri dari berbagai langkah karena memang penanganannya membutuhkan pemikiran yang sangat matang. Solusi yang telah dilakukan oleh BPKAD Provinsi Sumatera Utara yaitu dengan memberikan sosialisasi kepada pihak-pihak yang melakukan penyerobotan, pemasangan papan nama, berkoordinasi dengan pihak-pihak terkait, melakukan relokasi, dan bekerjasama dengan Satuan Polisi Pamong Praja selaku aparat penegak peraturan daerah. Muda et al (2017) memaparkan bahwa sejauh ini Pemerintah Provinsi Sumatera Utara berusaha mengajak masyarakat yang menempati aset pemerintah daerah untuk pindah ke rumah susun sederhana sewa yang disediakan oleh pemerintah daerah Provinsi Sumatera Utara yang berlokasi di daerah Kelurahan Namo Batang, Kecamatan Namorambe, Kabupaten Deli Serdang, Provinsi Sumatera Utara.

Terkait kendala yang terjadi selama dilakukannya proteksi hukum yaitu masih ada beberapa BMD yang belum tersertifikasi atau sudah tersertifikasi namun belum atas nama pemerintah daerah. kendala tersebut terjadi dikarenakan terbatasnya anggaran sertifikasi di setiap tahunnya, sehingga kegiatan proteksi hukum atas BMD dilakukan dengan cara bertahap. Mengatasi kendala tersebut langkah yang ditempuh BPKAD Provinsi Sumatera Utara yaitu melakukan pendataan terhadap BMD yang masih bermasalah agar dapat diurus 
sertifikasinya, serta selalu menganggarkan biaya untuk sertifikasi di setiap tahunnya meskipun terbatas.

Kemampuan BPKAD Provinsi Sumatera Utara dalam mengatasi setiap kendala yang terjadi sehubungan dengan pelaksanaan proteksi Barang Milik Daerah baik proteksi administrasi, proteksi fisik, dan proteksi hukum berbanding terbalik dengan hasil penelitian yang telah dilakukan oleh (Wanisa, 2016). Di mana pada penelitiannya Wanisa (2016) menjelaskan bahwa proteksi aset oleh Pemerintah Kota Surabaya masih menemui berbagai kendala dikarenakan kurangnya kualitas sumber daya manusia yang menyebabkan tidak efektifnya proteksi aset. Hasil penelitian ini juga berbanding terbalik dengan penelitian yang telah dilakukan oleh Suciyani (2013) yang mana hasil penelitiannya menjelaskan bahwa proteksi aset oleh Pemerintah Kota Bandung baik proteksi administrasi, fisik, maupun hukum belum berjalan secara efektif.

Terkait dengan akuntabilitas, hasil penelitian yang dilakukan oleh Arnitasari (2013) kembali bertolak belakang dengan hasil penelitian yang diperoleh peneliti. Arnitasari (2013) yang menemukan bahwa kegiatan proteksi aset Pemerintah Provinsi Jawa Timur belum efektif secara administrasi, fisik, dan hukum, namun sudah akuntabel. Pada penelitiannya Arnitasari (2013) menggunakan akuntabilitas publik menurut (Mardiasmo, 2013) sebagai dasar penelitian, sedangkan peneliti mendasarkan akuntabilitas dalam penelitian ini selain pada akuntabilitas publik menurut (Mardiasmo, 2013) peneliti juga melihat ada tidaknya kontribusi Barang Milik Daerah terhadap pendapatan asli daerah untuk melihat apakah BPKAD Provinsi Sumatera Utara sudah akuntabel atau belum.

Akuntabilitas yang dimaksud dalam penelitian ini adalah akuntabilitas publik menurut Wisdom \& Oyebisi (2017) di mana akuntabilitas tersebut terdiri atas empat dimensi, yaitu akuntabilitas kejujuran dan hukum, akuntabilitas proses, akuntabilitas program, dan akuntabilitas kebijakan, serta dengan melihat ada tidaknya kontribusi dari pemanfaatan BMD yang telah diamankan terhadap pendapatan asli daerah.

Pelaksanaan proteksi BMD oleh BPKAD Provinsi Sumatera Utara telah memenuhi semua aspek akuntabilitas publik. Akuntabilitas kejujuran dan akuntabilitas hukum dibuktikan dengan adanya pemisahan wewenang dalam kegiatan proteksi BMD, sedangkan untuk akuntabilitas hukumnya dapat dilihat dari telah sesuainya mekanisme proteksi BMD yang dijalankan dengan SOP dan peraturan perundang-undangan yang berlaku. Akuntabilitas proses tercermin dari adanya kejelasan sistem informasi dalam pencatatan BMD. Dalam hal ini informasi atas BMD tercantum pada Kartu Inventaris Barang (KIB). Akuntabilitas program yaitu telah tercapainya target atas BMD yang harus diamankan, dengan angka pencapaian sebesar $90 \%$ - 100\% pada setiap tahun anggaran, dan akuntabilitas kebijakan dibuktikan dengan telah dilakukannya pertanggungjawaban secara tertulis oleh BPKAD Provinsi Sumatera Utara kepada Walikota dan DPRD Provinsi Sumatera Utara. Dari penjabaran empat dimensi dalam akuntabilitas publik tersebut dapat diketahui bahwa BPKAD Provinsi Sumatera Utara sudah memenuhi unsur akuntabilitas publik.

Akuntabilitas BPKAD Provinsi Sumatera Utara dalam mengamankan Barang Milik Daerah selain dilihat dari terpenuhinya keempat aspek 
akuntabilitas publik di atas, juga dilihat dari ada tidaknya kontribusi dari BMD tersebut terhadap pendapatan asli daerah sebagai hasil dari pemanfaatan BMD tersebut. Bentuk pemanfaatan atas BMD oleh BPKAD Provinsi Sumatera Utara meliputi kerjasama sewa, kerjasama pemanfaatan (KSP), dan Bangung Guna Serah (BGS).

Kerjasama sewa merupakan kegiatan pemanfaatan atas BMD oleh pihak lain dalam waktu tertentu dengan imbal hasil berupa uang tunai. Data yang telah diperoleh peneliti menunjukkan adanya kontribusi atas BMD terhadap pendapatan asli daerah dari hasil kerjasama sewa. Kontribusi BMD terhadap pendapatan asli daerah dari hasil kerjasama sewa disajikan pada tabel 1. Dari tabel tersebut dapat dilihat bahwa pada tahun 2018 imbal hasil yang diperoleh dari pemanfaatan BMD dalam bentuk kerjasama sewa menunjukkan adanya peningkatan dari tahun 2017 yaitu berjumlah Rp 4.078.174.533,-. Peningkatan perolehan retribusi pemakaian kekayaan daerah pada tahun 2018 diperoleh dari kenaikan signifikan atas sewa tanah serta kenaikan signifikan atas sewa gedung dan bangunan.

Tabel 1. Realisasi Retribusi Pemakaian Kekayaan Daerah Tahun 2017-2018

\begin{tabular}{lrr}
\hline \multirow{2}{*}{ Uraian } & \multicolumn{2}{c}{ Total Realisasi } \\
\cline { 2 - 3 } & \multicolumn{1}{c}{ Tahun 2017 } & \multicolumn{1}{c}{ Tahun 2018 } \\
\hline Retribusi sewa tanah & 2.421 .229 .981 & 4.003 .792 .112 \\
Retribusi sewa gedung dan bangunan & 2.673 .689 .153 & 5.115 .411 .225 \\
Retribusi sewa kios & 557.113 .213 & 611.003 .543 \\
Total & 5.652 .032 .347 & 9.730 .206 .880 \\
\hline
\end{tabular}

Sumber: Laporan Keuangan BPKAD Provinsi Sumatera Utara, 2018

Bentuk pemanfaatan atas BMD yang dilaksanakan oleh BPKAD Provinsi Sumatera Utara yang kedua yaitu pemanfaatan dalam bentuk Kerjasama Pemanfaatan (KSP). KSP adalah pendayagunaan BMD oleh pihak lain dalam waktu tertentu dengan maksud untuk meningkatkan pendapatan asli daerah maupun sumber pembiayaan lainnya. BMD yang dimanfaatkan untuk KSP adalah kerjasama terkait plaza pemerintah daerah yang dipercayakan pengelolaannya kepada pihak ketiga karena pemerintah daerah mengalami kesulitan dalam mengelolanya. Data terkait berapa jumlah pasti imbal hasil yang diterima oleh pemerintah Provinsi Sumatera Utara dari KSP plaza pemerintah daerah tersebut tidak berhasil peneliti peroleh. Rincian data yang diberikan oleh pihak BPKAD Provinsi Sumatera Utara hanya terbatas pada rincian data pemanfaatan BMD dalam bentuk kerjasama sewa.

Bentuk pemanfaatan Barang Milik Daerah berikutnya berupa Bangun Guna Serah (BGS). BGS adalah kegiatan pemanfaatan BMD berwujud tanah oleh pihak lain melalui pendirian bangunan maupun sarana beserta prasarana, untuk selanjutnya diberdayakan dengan jangka waktu sesuai kesepakatan bersama. Di mana ketika telah habis jangka waktu yang telah disepakati maka akan dikembalikan tanah beserta bangunan termasuk sarana dan prasarana di dalamnya kepada pemerintah daerah. Berdasarkan pernyataan dari Kepala Sub Bidang Pendayagunaan Aset, contoh pemanfaatan BMD dalam bentuk Bangun Guna Serah yaitu kerjasama aset Sun City yang berlangsung selama 30 tahun, di mana nanti ketika telah berakhir masa perjanjian maka Sun City beserta segala 
fasilitas yang ada di dalamnya akan diserahkan kepada pemerintah daerah Provinsi Sumatera Utara.

Sejalan dengan data terkait pemanfaatan BMD dalam bentuk KSP, untuk BGS ini data yang diperoleh peneliti juga hanya terbatas pada jenis BMD yang dimanfaatkan dan jangka waktu pemanfaatannya, yaitu berupa Sun City Provinsi Sumatera Utara dengan jangka waktu selama 30 tahun. Sedangkan untuk data rincian perolehan imbal hasil atas BGS tersebut tidak berhasil peneliti dapatkan.

\section{SIMPULAN}

Berdasarkan hasil pemaparan dan analisis data yang telah disajikan, maka simpulan yang dijelaskan pada penelitian ini adalah, pelaksanaan proteksi BMD meliputi proteksi administrasi, proteksi fisik, dan proteksi hukum yang dilakukan BPKAD Provinsi Sumatera Utara sudah dilakukan dengan efektif. akan tetapi belum akuntabel. Hal tersebut dikarenakan akuntabilitas yang terpenuhi hanya berupa akuntabilitas publik yang meliputi akuntabilitas hukum dan kejujuran, akuntabilitas proses, akuntabilitas program, dan akuntabilitas kebijakan. Keterbatasan dalam penelitian ini yaitu tidak diperolehnya data terkait nominal imbal hasil yang didapatkan oleh BPKAD Provinsi Sumatera Utara dari kegiatan pemanfaatan BMD dalam bentuk Kerjasama Pemanfaatan (KSP) dan Bangun Guna Serah (BGS), sehingga peneliti tidak dapat menjabarkan secara jelas berapa kontribusi dari pemanfaatan BMD terhadap Pendapatan Asli Daerah.

Saran atas hasil penelitian ini adalah sebaiknya BPKAD Provinsi Sumatera Utara menggunakan aplikasi SIMDA Pendapatan dalam pengelolaan dan penatausahaan pendapatan asli daerah yang mendukung penyediaan dan penyajian data realisasi pendapatan asli daerah secara akurat dan menyeluruh sehingga proteksi atas BMD dalam mewujudkan Akuntabilitas di BPKAD Provinsi Sumatera Utara dapat lebih sempurna di kemudian hari.

\section{REFERENSI}

Arnitasari, N. (2013). Akuntabilitas Pemerintah Provinsi Jawa Timur dalam Pengelolaan Aset. Jurnal Kebijakan Dan Manajemen Publik, 1(1), 48-55.

Assey, T., Kalegele, K., \& Chachage, B. (2017). Evaluating Information System Integration approaches for fixed asset management framework in Tanzania. Journal of Systems Integration, 8(4), 3-11. https://doi.org/10.20470/jsi.v8i4.324

Fuchs, S., Bergmann, A., \& Brusca, I. (2017). Using financial reporting for decision making as a measure towards resilient government finances: The case of Switzerland. Lex Localis, 15(1), 133-153. https://doi.org/10.4335/15.1.133153(2017)

González, R. M. D., Ruíz, A. G., \& Bargues, J. M. V. (2018). The Recent Reform of Spanish Local Governmental Accounting: A Critical Perspective From Local Governmental Accountants as Internal Users of Budgeting And Financial Accounting Information. Lex Localis-Journal of Self-Government, 16(3), 453476. https://doi.org/10.4335/16.3.453-476(2018) 
He, B. Z., Krishnamurthy, A., \& Milbradt, K. (2016). What makes US government bonds safe assets? American Economic Review, 106(5), 519-523. https://doi.org/10.1257/aer.p20161109

Henoch, R. W., \& Sauter, B. J. A. (2016). Innocent Foundations Beware: The US Government's Far-Reaching Power of Civil Asset Forfeiture, and What Innocent Foundations and Other Fiduciaries Need to Know to Prepare. Trusts $\mathcal{E}$ Trustees, 22(6), 605-611. https://doi.org/10.1093/tandt/ttw059

Hinrichs, U., Carpendale, S., Knudsen, S., \& Thudt, A. (2017). Analyzing qualitative data. Proceedings of the 2017 ACM International Conference on Interactive Surfaces and Spaces, ISS 2017. https://doi.org/10.1145/3132272.3135087

Irwin, T. (2015). The Whole Elephant: A Proposal for Integrating Cash, Accrual, and Sustainability-Gap Accounts. IMF Working Papers, 15(261), 1. https://doi.org/10.5089/9781513597492.001

Kaganova, O., \& Telgarsky, J. (2018). Management of Capital Assets by Local governments: An Assessment and Benchmarking Survey. International Journal of Strategic Property Management, 22(2), 143-156. https://doi.org/10.3846/ijspm.2018.445

Lee, S. H., Park, S., \& Kim, J. M. (2015). Suggestion for a Framework for a Sustainable Infrastructure Asset Management Manual in Korea. Sustainability (Switzerland), 7(11), 15003-15028. https://doi.org/10.3390/su71115003

Mardiasmo, M. (2013). Assessing Accountability Of Performance Measurement System And Local Government Budgetary Management. Gadjah Mada International Journal of Business, 4(3), 373-395. https:// doi.org/10.22146/gamaijb.5388

Maxwell, J. A., \& Reybold, L. E. (2015). Qualitative Research. In International Encyclopedia of the Social $\mathcal{E}$ Behavioral Sciences: Second Edition. https://doi.org/10.1016/B978-0-08-097086-8.10558-6

Moen, K., \& Middelthon, A. L. (2015). Qualitative Research Methods. In Research in Medical and Biological Sciences: From Planning and Preparation to Grant Application and Publication. https://doi.org/10.1016/B978-0-12-7999432.00010-0

Muda, I., Ismail, M., \& Marhayanie, M. (2017). Impact of Capital Expenditure Allocation on The Local Government Assets and the role of Revenue Sustainability: Evidence from North Sumatra. International Journal of Economic Perspectives, 11(2), 110-123.

Rothschild, D. Y., \& Block, W. E. (2016). Don't steal; the government hates competition: The problem with civil asset forfeiture. Journal of Private Enterprise, 31(1), 45-56.

Suciyani, W. O. (2013). Optimasi Pemanfaatan Aset Pemerintah sebagai Upaya Revitalisasi Kawasan Alun-Alun Kota Bandung. Jurnal Pembangunan Wilayah E Kota, 9(2), 144-151.

Wanisa, Z. (2016). Kinerja Pegawai Dinas Pengelolaan Bangunan Dan Tanah dalam Pelaksanaan Inventarisasi Aset Tanah di Kota Surabaya. Jurnal Kebijakan Dan Manajemen Publik, 4(2), 34-45. 
Wisdom, O., \& Oyebisi, O. M. (2017). Impact of Public Sector Auditing in Promoting Accountability and Trasparency in Nigeria. Journal of Internet Banking and Commerce, 22(3), 1-8.

Zeng, Y., \& McLaren, J. (2015). The Impact of Large Public Sales of Government Assets: Empirical Evidence From The Chinese Stock Markets On A Gradual and Offer-To-Get Approach. Review of Quantitative Finance and Accounting, 45(1), 137-173. https:// doi.org/10.1007/s11156-014-0433-9 